Научная статья

УДК 372.881 .161 .1

DOI: $10.18101 / 2307-3330-2021-1-93-98$

\title{
СОДЕРЖАТЕЛЬНО-ТЕХНОЛОГИЧЕСКИЕ АСПЕКТЫ ПРЕПОДАВАНИЯ РУССКОГО ЯЗЫКА В КИТАЕ
}

\author{
(C) Тулунова Соёлма Владимировна \\ преподаватель русского языка, \\ Хулунбуирский институт \\ Китай, 021000, г. Хулунбуир, ул. Чингисхан Миддл Роуд, 26 \\ stulunov@mail.ru
}

\begin{abstract}
Аннотация. В статье рассматривается проблема совершенствования преподавания русского языка в Китае в современных условиях глобализации. Охарактеризованы средства методического сопровождения изучения русского языка в Китае: журнал «Обучение русскому языку в Китае», конференция «Создание учебных пособий по русскому языку и методика обучения русскому языку», учебно-методический комплекс «Русский язык» (новый «Восток»), единый комплекс «Учимся вместе в Шэньчжэне». Автор считает, что необходимо активнее использовать возможности цифровых образовательных ресурсов и технологий, в том числе модели смешанного обучения, смарт-технологий. В современной образовательной практике преподавания русского языка как иностранного (РКИ) нужно учитывать положительные эффекты дистанционного/онлайн-обучения.
\end{abstract}

Ключевые слова: преподавание русского языка, Китай, образовательная практика, цифровые технологии

\section{Для цитирования}

Тулунова С. В. Содержательно-технологические аспекты преподавания русского языка в Китае // Вестник Бурятского государственного университета. Образование. Личность. Общество. 2021. Вып. 1. С. 93-98.

Главной заботой мирового сообщества является устойчивое восстановление мировой экономики после пандемии и переосмысление мировой политики. В этом контексте современные российско-китайские отношения официально определяются сторонами как отношения всеобъемлющего партнерства и стратегического взаимодействия, развивающиеся на основе Договора о добрососедстве, дружбе и сотрудничестве (16 июля 2001 г.). Между странами заключено более 300 межправительственных договоров и соглашений, которые охватывают практически все области сотрудничества.

Несомненно, важнейшей характеристикой развития российско-китайских отношений является изучение русского языка в Китае. Так, в более чем 450 китайских вузах русский язык изучается на профессиональном уровне [10]. Первый опыт создания школы русского языка зафиксирован во времена династии Цин (1708), когда был открыт Дом русского языка. Через 90 лет (1798) был издан первый учебник русского языка, а в 1862 г. «Школа русского языка» была введена в состав училища иностранных языков «Тонвэнь», где осуществлялась подго- 
товка переводчиков и дипломатов для императорского двора. В годы СССР в Шанхайском университете (1921) были организованы курсы русского языка, в Яньаньском университете (1941) была создана кафедра русского языка, к 1949 г. в тринадцати школах северо-восточных и северных регионов Китая открылись курсы русского языка. Стабильный интерес к русскому языку в Китае наблюдался на протяжении 50 лет (1949-2000).

В условиях глобализации средством международного общения стал английский язык, поэтому из общего числа китайских школьников (197 миллионов) русский язык изучают в трех провинциях в Северо-Восточного Китая и Внутренней Монголии (470 000 студентов). Количественные показатели изучения русского языка в Китае во многом зависят от социально-политической обстановки. Будем надеяться, что в 2020-2021 гг. - годы российско-китайского научнотехнического и инновационного сотрудничества - активизируют культурнообразовательные проекты.

В статье уделено особое внимание содержательным и технологическим аспектам изучения русского языка в Китае, поскольку они определяют качество образовательного процесса. Методическое сопровождение изучения русского языка в Китае началось в 1981 г., когда в структуре Китайско-русской учебноисследовательской ассоциации был основан журнал «Обучение русскому языку в Китае». Значимым событием современной методической базы преподавания русского языка в Китае стала межвузовская конференция «Создание учебных пособий по русскому языку и методика обучения русскому языку» (11-12 июля 2009 г.) [5].

В настоящее время наиболее распространенным учебником по русскому языку для студентов в Китае является учебно-методический комплекс «Русский язык» (новый «Восток») [11], также активно используются другие учебники: «Чтение русской культуры», «Художественный анализ шедевров классиков русской литературы», «Курс страноведения России», «Практический курс сочинения на русском языке», «Базовый аудиовизуальный курс русского языка», «Как писать деловые бумаги и научные работы», разработанные китайскими авторами. Bсе учебные пособия снабжены большим количеством упражнений, которые обеспечивают последовательное многократное повторение и закрепление изучаемого лексико-грамматического материала и доводят речевые навыки до автоматизации.

Преподаватели-русисты Московского государственного университета создали единый комплекс «Учимся вместе в Шэньчжэне», направленный на формирование основ правильного четкого произношения, развитие навыков и умений для профессионального общения в устной и письменной формах:

- Введение в язык специальности. Математика. Химия: учебное пособие / под ред. Т. В. Картава, И. В. Одинцовой; пер. Л. А. Радус; науч. ред. материалов по химии Е. В. Мещерякова. Москва: Макс-Пресс, 2017. 136 с. (Сер. «Учимся вместе в Шэньчжэне); 
- Введение в язык специальности. Экономика: учебное пособие / под ред. Т. В. Картава, И. В. Одинцовой; пер. Л. А. Радус. Москва: Макс-Пресс, 2017. 136 с. (Сер. «Учимся вместе в Шэньчжэне) и др.

В условиях развития цифровых образовательных технологий отмечается методический интерес к сетевым ресурсам [9]. Предлагается активно использовать поисковые системы (онлайн-словари), организовывать электронную переписку как средство создания коммуникативной ситуации для изучения языка. Нужно стимулировать участие в онлайн-чатах для улучшения навыков невербального общения, тематических онлайн-форумах, чтобы обучающиеся учились свободно высказывать личное мнение, комментировать мнение других. Хорошим средством изучения языков становятся аудиовизуальные ресурсы (подкасты: новости, литература, культура) - источники оригинальных аутентичных материалов для изучения устного русского языка. Полезными ресурсами являются «Русское национальное радио» (www.radiorus.ru), радио «Эхо Москвы» (www.vor.ru), «Маяк» (www.radiomayak.ru), www.ruinfo.net.cn («Русский салон», «Чайная комната Катюша», «Русская литература», «Живописный пейзаж СНГ», «Логические игры»), русская версия China Radio International и др.

Чжан Цзыли отмечает, что цифровые технологии обеспечивают индивидуализацию, интерактивность в условиях специальной обучающей среды, открывая новые пути формирования коммуникативной компетенции [9].

В последние годы обсуждается возможность использования модели смешанного обучения на уроках преподавания РКИ в китайских вузах [3], что позволит усилить роль самостоятельного обучения. Условиями реализации смешанного обучения являются качественная подготовка преподавателей, готовность студентов к самостоятельному и совместному обучению, информационная грамотность учащихся, наличие инструментов оценки эффективности смешанного обучения. Специалисты признают, что цифровой обучающий ресурс имеет большое количество достоинств как образовательный инструмент (обширный наглядный материал, интерактивные упражнения, игровые компоненты) [12].

Обращение к цифровым ресурсам возможно на начальном этапе обучения РКИ (уровни А1-А2) в целях формирования и развития фонетических навыков, формирования и пополнения лексического запаса; развития навыков аудирования, говорения, первоначальных навыков чтения и письма. На продвинутом этапе обучения (уровни В1-В2) применяются цифровые ресурсы, имеющие информацию страноведческого характера, аутентичные тексты, аудио- и видеоматериалы. На уровне C1-С2 используются аудиокниги, тексты на языке специальности.

Цифровые образовательные ресурсы помогают при обучении аудированию, поскольку появляется возможность прослушать и повторить материал обучающего характера; прослушать слово или высказывание и найти соответствующую картинку с целью контроля степени запоминания лексических единиц; узнать слово на слух (учебно-игровые задания); отгадать загадки; прослушать текст и выявить ключевую информацию (заполнить таблицу); в процессе прослушивания ряда слов повторить только те из них, которые связаны с изучаемой темой; прослушать текст и выполнить задание «да - нет» / «правда - неправда»; по- 
вторить за диктором слова и фразы; дать ответ на вопрос, правильный вариант которого впоследствии можно прослушать; прослушать вопрос и выбрать один из предложенных вариантов ответа [12].

В условиях цифровизации образовательного процесса эффективное преподавание РКИ предполагает умение осуществлять корректный поиск информации, реализовать электронное обучение, создавать авторские электронные учебнометодические материалы, организовать онлайн-обучение.

Специалисты выделяют преимущества и недостатки обучения студентов русскому как иностранному при помощи цифровых технологий. Преподавателей и студентов удовлетворяют плюсы дистанционного обучения: прозрачный контроль самостоятельной работы студентов, низкая себестоимость, отсутствие временных ограничений обратной связи с преподавателем, интерактивное взаимодействие с учебными материалами, разнообразие и большой объем учебной информации (и прежде всего для профессиональной лексики) и другие.

К недостаткам дистанционного обучения, снижающим эффективность преподавания РКИ, относятся [6] ограничения для реализации индивидуального подхода; отсутствие «живого» общения и отсюда недостаточные условия для развития навыков аудирования и разговорной практики; технические проблемы организации дистанционного обучения; трудности для социокультурной адаптации и межкультурной коммуникации и т. д.

В этой связи следует обратить внимание на образовательный потенциал смарт-технологий: 1) онлайн-словари; 2) учебные материалы в формате интерактивных презентаций; 3) рабочие интерактивные листы с элементами мультимедиа; 4) платформы и инструменты для общения и коммуникации в режиме реального времени [2], а также смарт-ресурсы (Padlet, Google classroom, Canvas Network и Stepik). С помощью смарт-технологий реализуется цифровая лексикографика - накопление и обработка информации о частотности обращения иностранных студентов к лексике определенной тематики и применении в речевых ситуациях, моделирование списков авторов и составителей, литературных источников, комментариев и статей в электронных словарях и т. д. Таким образом, повышается роль образовательных смарт-технологий в процессе обучения русскому языку как иностранному.

Некоторые авторы предлагают активно использовать возможности индивидуальных онлайн-занятий в изучении РКИ: индивидуальная траектория; индивидуализация обучения (учет психофизиологических и когнитивных особенностей, профессионального и жизненного опыта, уровня языковой и компьютерной компетенции и т. д.); ориентация на результат, а не на прохождение запланированной программы обучения; преобладание речевой практики; неформальная, дружеская атмосфера занятия; продуктивная обратная связь; отсутствие конкурентной среды; гибкость обучения; отсутствие формального контроля.

Как видим, современная образовательная практика преподавания РКИ учитывает положительные эффекты дистанционного/онлайн-обучения. В использовании цифровых технологий необходимо учитывать принцип педагогической целесообразности применения средств новых информационных технологий, тре- 
бующий педагогической оценки каждого шага проектирования, создания и организации дистанционного обучения [1].

На основании политики Национальных стандартов качества преподавания в Китае обучение студентов должно быть организовано в соответствии их способностями, целями и содержанием обучения. При этом необходимо уделять особое внимание эвристическим, дискуссионным и интерактивным методам обучения. Предполагается разумное использование современных образовательных технологий, усиливающих учебные эффекты.

Таким образом, в преподавании русского языка в Китае необходимо учитывать современный опыт методики РКИ, сочетающей лучшие интерактивные образовательные технологии и возможности цифровых технологий. Достижение этой цели вполне реально, так как облачные технологии, большие данные, искусственный интеллект, виртуальная реальность и другие новации широко применяются в китайском образовании ${ }^{1}$. В связи с тем, что в стране приобретает популярность электронное обучения, создана единая система контроля программы электронного обучения и освоения данной программы студентами на территории всей Китайской Народной Республики [4].

Литература

1. Андреев А. А. Педагогика высшей школы. Новый курс. Москва: Изд-во Московского международного института эконометрики, информатики, финансов и права, 2002. 264 с. Текст: непосредственный.

2. Белоусов Д. Практика применения образовательных смарт-технологий в обучении русскому языку как иностранному // Cross Cultural Studies: Education and Science. 2020. № 2. C. 122-128. DOI:10.24411/2470-1262-2020-10084. Текст: непосредственный.

3. Ван Сяоян. Модель смешанного обучения русскому языку как иностранного в Китае // Педагогическое образование в России. 2016. № 7. С. 244-249. Текст: непосредственный.

4. Ларина Е. Д. Предпосылки и социальные последствия цифровизации системы образования в России и Китае // Вестник Санкт-Петербургского университета. Социология. 2020. Т. 13, вып. 1. С. 102-112. Текст: непосредственный.

5. Лие Ван. Уроки русского языка в Китае // Слово.ру: Балтийский акцент. 2010. № 1-2. С. 301-303. Текст: непосредственный.

6. Саенко Н. Р. Роль цифровых технологий в процессе обучения студентовиностранцев русскому как иностранному // Сервис Plus. 2020. T. 14, № 3. C. 94-102. DOI: 10.24411/2413-693X-2020-10311. Текст: непосредственный.

7. Чжан Цзин. Применение сетевых ресурсов в преподавании русского языка в Китае // Современное педагогическое образование. 2020. № 1. С. 81-83.

8. Чжан Цзыли. Методические основы использования ресурсов интернета при обучении русскому языку как иностранному (в условиях китайского языкового вуза): диссертация на соискание ученой степени кандидата педагогических наук: 13.00.02. Москва, 2002. 164 c.

\footnotetext{
${ }^{1}$ Системы образования России и Китая меняются под воздействием цифровых технологий / Новости. Национальный исследовательский университет «Высшая школа экономики». URL: https://www.hse.ru/news/308211791.html (дата обращения: 20.03.2021). Текст: электронный.
} 
9. Шан Цзиньюй. Обогащение словарного запаса китайских студентов-филологов культурно-маркированной лексикой // Мир науки, культуры, образования. 2021. № 1(86). С. 111-114. Текст: непосредственный.

10. Восток: учебник русского языка / главный редактор Ши Тецян. Пекин, 2010. Ч. 5. 225 с. Текст: непосредственный.

11. Яппарова В. Н., Мифтахова А. Н. Место цифровых ресурсов в арсенале обучающих средств преподавателя русского языка как иностранного // Филология и культура. 2019. № 4(58). С. 223-228. Текст: непосредственный.

Статья поступила в редакиию 09.03.2021; одобрена после рецензирования 25.03.2021; принята к публикаџии 09.04.2021.

\title{
CONTENT AND TECHNOLOGICAL ASPECTS OF RUSSIAN LANGUAGE TEACHING IN CHINA
}

\author{
Soelma V. Tulunova \\ Russian Language Teacher, \\ Hulunbuir Institute \\ 26 Genghis Khan Middle Road, Hulunbuir, China \\ stulunov@mail.ru
}

Abstract. The article discusses the problem of improving Russian language teaching in China. It is emphasized that interest in the Russian language is declining in the current conditions of globalization. We have characterized the means of methodological support of Russian language teaching in China, such as the magazine "Teaching Russian language in China", the conference "Making Russian Language Textbooks and Russian Language Teaching Methods", the educational and methodical complex "Russian language" (new "Vostok"), the unified complex "Learning Together in Shenzhen". We believe that it is necessary to actively use the digital educational resources and technologies, including blended learning models, smart technologies. Modern educational practice of Russian language teaching should take into consideration the positive effects of distance/online learning.

Keywords: Russian language teaching; China; educational practice; digital technologies.

For citation

Tulunova S. V. Content and Technological Aspects of Russian Language Teaching in China. Education. Person. Society. 2021; 1: 93-98 (In Russ.).

The article was submitted 09.03.2021; approved after reviewing 25.03.2021; accepted for publication 09.04.2021. 